Operette Morali

Essays and Dialogues

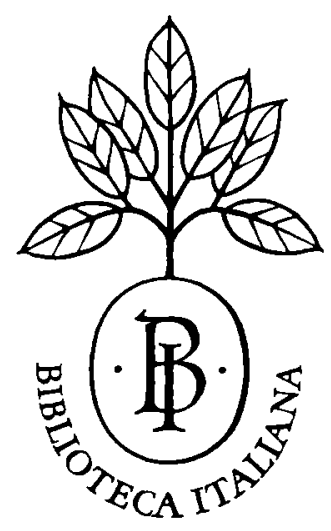




\section{B I BLIOTECA ITALIANA}

This series is conceived as a library of bilingual editions of works chosen for their importance to Italian literature and to the international tradition of art and thought Italy has nurtured.

In each volume an Italian text in an authoritative edition is paired with a new facing-page translation supplemented by explanatory notes and a selected bibliography. An introduction provides a historical and critical interpretation of the work. The scholars preparing these volumes hope through Biblioteca Italiana to point a straight way to the Italian classics.

General editor: Louise George Clubb

EDITORIAL BOARD

Paul J. Alpers, Vittore Branca

Gene Brucker, Fredi Chiappelli

Phillip W. Damon, Robert M. Durling

Gianfranco Folena, Lauro Martines

Nicolas J. Perella

UNIVERSITY OF CALIFORNIA

UNIVERSITY OF PADUA 


\title{
Operette Morali
}

\section{Essays and Dialogues}

\author{
Giacomo Leopardi
}

\author{
TRANSLATED \\ WITH INTRODUCTION \\ AND NOTES BY \\ GIOVANNI CECCHETTI
}

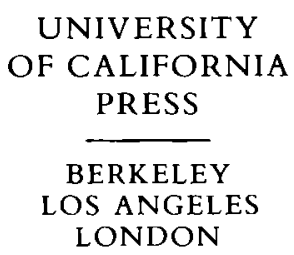


University of California Press Berkeley and Los Angeles, California

University of California Press, Ltd. London, England

(C) 1982 by

The Regents of the University of California

Library of Congress Cataloging in Publication Data

Leopardi, Giacomo, 1798-1837.

Operette morali.

(Biblioteca italiana)

English and Italian.

I. Cecchetti, Giovanni, I922- II. Title.

III. Series.

PQ4709.E5A13 $1982 \quad 854^{\prime} .7 \quad 82-2627$

ISBN 0-520-04704-4 AACR2

Printed in the United States of America

$\begin{array}{lllllllll}1 & 2 & 3 & 4 & 5 & 6 & 7 & 8 & 9\end{array}$ 